\title{
African Great Ape Population Trends by Taxon, in Descending Order of Abundance
}

\begin{tabular}{|c|c|c|c|c|c|c|}
\hline Taxon & Abundance & Trend & $\begin{array}{l}\text { Annual rate } \\
\text { of change }\end{array}$ & $\begin{array}{l}\text { Total estimated } \\
\text { change }\end{array}$ & $\begin{array}{l}\text { Period } \\
\text { assessed }\end{array}$ & Source \\
\hline $\begin{array}{l}\text { Western lowland } \\
\text { gorilla } \\
\text { Gorilla gorilla gorilla }\end{array}$ & $\begin{array}{l}361,919 \\
(302,973-460,093)\end{array}$ & Declining & $-2.7 \%$ & $-19.4 \%$ & $2005-13$ & Strindberg et al. (2018) \\
\hline $\begin{array}{l}\text { Eastern } \\
\text { chimpanzee } \\
\text { Pan troglodytes } \\
\text { schweinfurthii }\end{array}$ & $181,000-256,000$ & Declining & $-5.1 \%$ & $\begin{array}{l}-22 \% \text { to }-45 \% \\
\text { in eastern DRC } \\
\text { only }\end{array}$ & $\begin{array}{l}1994- \\
2015\end{array}$ & $\begin{array}{l}\text { Plumptre et al. } \\
(2015,2016 a)\end{array}$ \\
\hline $\begin{array}{l}\text { Central } \\
\text { chimpanzee } \\
\text { Pan t. troglodytes }\end{array}$ & $\begin{array}{l}128,760 \\
(114,208-317,039)\end{array}$ & Declining $^{a}$ & $\mathrm{n} / \mathrm{a}$ & $\mathrm{n} / \mathrm{a}$ & $2005-13$ & Maisels et al. (2016) \\
\hline $\begin{array}{l}\text { Western } \\
\text { chimpanzee } \\
\text { Pan t. verus }\end{array}$ & $\begin{array}{l}52,800 \\
(17,577-96,564)\end{array}$ & Declining & $-6.53 \%$ & $-80.2 \%$ & $\begin{array}{l}1990- \\
2014\end{array}$ & Heinicke et al. (2019) \\
\hline \multirow{2}{*}{$\begin{array}{l}\text { Bonobo } \\
\text { Pan paniscus }\end{array}$} & \multirow{2}{*}{$\begin{array}{l}15,000-20,000 \\
\text { minimum }\end{array}$} & \multirow[t]{2}{*}{ Declining } & $-5.95 \%^{\mathrm{b}}$ & $-54.9 \%$ & 2003-15 & \multirow[t]{2}{*}{ Fruth et al. (2016) } \\
\hline & & & $-1 \%^{\mathrm{c}}$ & $>-50 \%$ & $2003-78$ & \\
\hline $\begin{array}{l}\text { Nigeria- } \\
\text { Cameroon } \\
\text { chimpanzee } \\
\text { Pan t. ellioti }\end{array}$ & $4,400-9,345$ & Declining & $\begin{array}{l}-0.92 \% \text { to } \\
-2.14 \%\end{array}$ & $-50 \%$ to $-80 \%$ & $\begin{array}{l}1985- \\
2060\end{array}$ & $\begin{array}{l}\text { R. Bergl, A. Dunn, } \\
\text { L. Gadsby, R.A. Ikemeh, } \\
\text { I. Imong, J.F. Oates, } \\
\text { F. Maisels, B. Morgan, } \\
\text { S. Nixon and E.A. } \\
\text { Williamson, personal } \\
\text { communication, } 2018\end{array}$ \\
\hline $\begin{array}{l}\text { Grauer's gorilla } \\
\text { Gorilla beringei } \\
\text { graueri }\end{array}$ & $\begin{array}{l}3,800 \\
(1,280-9,050)\end{array}$ & Declining & $-7.34 \%$ & $-77 \%$ & $\begin{array}{l}1994- \\
2015\end{array}$ & $\begin{array}{l}\text { Plumptre et al. } \\
(2015,2016 \mathrm{c})\end{array}$ \\
\hline $\begin{array}{l}\text { Mountain gorilla } \\
\text { Gorilla b. beringei }\end{array}$ & $>1,000$ & Increasing & $+3.7 \%$ & $+26 \%$ & 2003-10 & $\begin{array}{l}\text { Gray et al. (2013); } \\
\text { Hickey et al. (2018); } \\
\text { Roy et al. (2014) }\end{array}$ \\
\hline $\begin{array}{l}\text { Cross River gorilla } \\
\text { Gorilla g. diehli }\end{array}$ & $<300$ & Declining & $\mathrm{n} / \mathrm{a}$ & $\mathrm{n} / \mathrm{a}$ & $\mathrm{n} / \mathrm{a}$ & $\begin{array}{l}\text { Dunn et al. (2014); } \\
\text { R. Bergl and J. Oates, } \\
\text { personal communica- } \\
\text { tion, } 2000\end{array}$ \\
\hline
\end{tabular}

Notes: Abundance estimates for mountain gorillas include infants; all other estimates represent the number of weaned individuals capable of building nests. Estimates are based on both surveys and spatial predictions. The $95 \%$ confidence intervals appear in parentheses.

Due to variations in modeling approaches, the taxon-specific estimates per country are not necessarily equivalent to the sums of regional estimates per country. All estimates at taxon level were derived from modeling approaches in the source publications, except for the Cross River gorilla, mountain gorilla and the Nigeria-Cameroon chimpanzee.

a While Strindberg et al. (2018) do not detect any statistically significant change in central chimpanzee numbers, they note that it is unlikely that the population remained stable between 2005 and 2013. Moreover, Maisels et al. (2016) observe: "Given the scale of the poaching problem across Central Africa, this taxon is likely to be experiencing declines significant in terms of the population status, which we do not have the statistical power to detect."

b The confidence interval for this analysis is very large, suggesting uncertainty in the data.

c A $1 \%$ decline per year would yield more than a $50 \%$ reduction of the bonobo population for the period 2003-78.

Source: GRASP and IUCN (2018, table 4) 